\title{
Modelling the financial stability of an enterprise taking into account macroeconomic indicators
}

\author{
Davit S. Bidzhoyan \\ Postgraduate Student, Department of Business Analytics, Doctoral School of Economics \\ National Research University Higher School of Economics \\ Address: 20, Myasnitskaya Street, Moscow, 101000, Russian Federation \\ E-mail: bidzhoyan_david@mail.ru
}

\section{Tatiana K. Bogdanova}

Associate Professor, Department of Business Analytics

National Research University Higher School of Economics

Address: 20, Myasnitskaya Street, Moscow, 101000, Russian Federation

E-mail: tanbog@hse.ru

\begin{abstract}
Nowadays enterprises operate in a rapidly changing macroeconomic environment, and this factor should be taken into account when forecasting a company's financial statement as a whole, or some of its particular aspects. However, development of the company's financial stability assessment model taking into account macroeconomic factors is hampered by the problem of inclusion in the model of some factors with frequency of measurement different from that of the internal financial performance. For example, currency rates and crude oil prices can change on a daily, weekly, or monthly basis. Changes in the key interest rate cannot be characterized as systematic, since the Central Bank can vary the key interest rate depending on market conditions. Meanwhile, financial indicators of the company are published in the semi-annual and annual reports.

This paper proposes an approach that aggregates macroeconomic factors, which means presenting a time series of each variable for each year, followed by the inclusion of polynomial coefficients in the final model as reference variable characteristics. The weighted average is calculated for the key interest rate, where the weights are the days during which the rate is operated. Based on the data of 291 metallurgical industry enterprises of the Volga federal district for the period 2012-2014, a financial stability assessment model has been built relying on the decision tree model using CRT (Classification and Regression Tree). The accuracy of the model is approximately $86 \%$. The decision tree structure has served as a basis for recommendations to optimize certain financial indicators of operations to reach financial stability.
\end{abstract}

Key words: financial stability, aggregation of macro-economic factors, polynomial function, decision tree, inventories, net assets, fixed assets, key interest rate, consumer price index.

Citation: Bidzhoyan D.S., Bogdanova T.K. (2016) Modelling the financial stability of an enterprise taking into account macroeconomic indicators. Business Informatics, no. 3 (37), pp. 30-37. DOI: 10.17323/1998-0663.2016.3.30.37.

\section{Introduction}

I nstitutions of stock and currency markets, global trade in goods produced by manufacturers from different countries and the oil trade determine the macroeconomic environment in which a company operates. This is not a complete list of parameters that characterize the macroeconomic situation. They may also include the consumer price index, unemployment and interest rates on loans and deposits, that are largely determined by the size of the key interest rate, and other indicators. For example, changes in exchange rates have a direct impact on enterprises conducting international activities, and indi- 
rectly affect enterprises with a domestic market orientation through structural changes in the economy. However, the abovementioned parameters' nature and degree of influence on the financial state of a company are uncertain. Moreover, the impact of changes in these parameters may have different effects on enterprises' performance depending on the nature of their interaction with the environment. For example, whether they carry out procurement of raw materials in foreign currencies, where are the primary market channels, etc. The financial condition of a company heavily depends on its ability to quickly adapt to the macroeconomic conditions.

Thus, the relevance of this study is based on the necessity to consider the macroeconomic factors when forecasting an enterprise's financial condition.

\section{Review of existing methods of forecasting an enterprise's financial state}

In the course of the last 80 years different methods and models of forecasting the financial condition of a company have been developed and applied.

The first attempts of such modelling were made in the 1960s. W. Beaver [1] proposed an expert assessment model of financial instability depending on financial flows. The conclusion was based on the analysis of trends in business performance of 79 industries turned bankrupt during the period from 1954 to 1964. Six indicators were selected:

$\downarrow$ the ratio of cash flow to the total debt;

$\checkmark$ the ratio of net profit to total assets;

$\checkmark$ the ratio of total liabilities to total assets;

$\checkmark$ the ratio of working capital to total assets;

$\downarrow$ liquidity ratio;

$\checkmark$ current assets minus current liabilities.

As a result, the analysis revealed a trend toward performance degradation of bankrupt enterprises, and the uptrend of financially healthy companies. The disadvantage of this approach is the difficulty of interpreting the results in the condition of divergent changes in the coefficients.

E. Altman's Z-score model (1968) [2] of multiple discriminant analysis (MDA) overcame the drawbacks of the W. Beaver's model. The MDA model is a derivation of an integral index on which the conclusion for the analyzed aspect of the financial condition is based. The model is as follows:

$$
Z=a_{1} X_{1}+a_{2} X_{2}+\ldots+a_{i} X_{i}
$$

where $Z$ - scoring value;

$a_{i}$ - coefficients of the variables;

$X_{i}$ - the factors determining the value of scoring.
In essence, this model is a model of regression analysis of a finite number of determining factors. The best known models are those of two-, five- and seven-factor models. Based on an MDA, a huge number of models was developed, both foreign and domestic. E. Deakin [3] puts forward a requirement on allocation normality of model factors values that is very difficult to achieve in practice. The idea of using a dynamic model of MDA, with the inclusion of lagged variables belongs to R. Edmister [4]. The use of standard deviations made it possible to increase the predictive accuracy of the model. M. Blum [5] applied the MDA to assess the probability of bankruptcy by maximizing the difference between bankrupt enterprises and financially healthy businesses, while minimizing the differences within each group.

The most popular method among modern scientists when analyzing solvency and bankruptcy of an enterprise is the logistic regression model constructed by D. Chesser [6]. One of the advantages of logistic regression is obtaining the probability of the analyzed event. In addition, there are various tools that can be used to obtain additional information on the model factors. This greatly facilitates the decision-making process. Those tools are ROC-curves, imaging quality of predictive models; marginal effects, showing the change in the probability of an event when each predictor changes by 1 , and others. These features greatly facilitate the decision making process. Among foreign studies on this issue, J. Olson's study is the best known [7]. Among Russian scholars, we should mention publications of T. Bogdanova and Yu. Alekseeva [8]. In the case of nonlinear relationships between the dependent variable and the independent factors, the most preferred method is the use of neural networks, because neural networks are universal approximations, allowing us to identify any hidden dependencies between variables. The advantage of neural networks is the absence of data requirements (normal distribution, "the curse of dimensionality", multicollinearity, etc.). The Neural Network toolbox is so wide/extensive that the problem of bankruptcy prediction (solvency) can be solved in different ways. One of them is a hybrid method based on the Bayesian neural network ensemble and logit model [9]. The problem also can be solved by means of classification by neural networks [10], clustering by self-organizing Kohonen maps. However, despite the versatility of this method, there are some drawbacks related with selecting the type of model from a large number of different parameters (number of hidden layers, the kind of activation function, etc.), the problem of retraining, etc. If there are linear relationships between variables, classic regression models show a better result compared with neural networks [11]. 


\section{Testing the classic models in a period of crisis}

The afore-mentioned and comparable models were designed and tested in a relatively stable macroeconomic situation: the absence of large, significant fluctuations in financial and currency markets, a situation beneficial both for industries and enterprise activities. Thus, it was not necessary to include macro-economic factors in the model due to their relative permanency. This observation has been confirmed by the high predictive accuracy of models: in Altman's model, bankruptcy prediction accuracy for a year was $95 \%$, while neural networks provided a predictive accuracy of approximately $87 \%$.

We hypothesize that the prediction accuracy of the selected models in the 2014 crisis hould had to be reduced, due to unstable macroeconomic environment. In this situation, the role of management is leveled out, since it is difficult to adapt to the rapidly changing realities. Working out a strategy for development, changing the price policy and financial activities are not easy, especially for large enterprises with an advanced and large administrative apparatus.

Table 1 shows the test results of some models of multiple discriminant analysis on the data from metallurgical enterprises of the Volga Federal District in 2014.

\section{Accuracy of classical models}

\begin{tabular}{c|c}
\hline Model & Model acouracy \\
\hline 2-factor Altman model & $33.20 \%$ \\
\hline 5-factor Altman model & $16.50 \%$ \\
\hline Taffler \& Tisshaw model & $28.08 \%$ \\
\hline Savitskaya model & $64.03 \%$ \\
\hline
\end{tabular}

The afore-mentioned models show low predictive ability. The foreign model of multiple discriminant analysis proved to be inadequate to predict the financial stability of domestic (Russian) companies. Savitskaya's model, adapted for the Russian economy, showed a higher predictive accuracy, but proved insufficient for sound decision making.

\section{Information base of the research}

771 observations from 291 enterprises of the metallurgical industry in the Volga Federal District organized as "joint-stock companies", in terms of public financial statements (forms 1 and 2) for 2012-2014 were taken as the sample for analysis. The sample includes successfully working as well as financially unstable companies (Table 2).

Table 2.

\section{Frequency analysis}

\begin{tabular}{c|c|c|c}
\hline & Frequency & Percent & $\begin{array}{c}\text { Cumulative } \\
\text { Percent }\end{array}$ \\
\hline Financially unstable firms & 440 & 57.1 & 57.1 \\
\hline Financially stable firms & 331 & 42.9 & 100,0 \\
\hline Total & $\mathbf{7 7 1}$ & $\mathbf{1 0 0 . 0}$ & \\
\hline \multicolumn{2}{|l}{}
\end{tabular}

As shown in Table 2, 440 of 771 observed firms are recognized as financially unstable, that is $57.1 \%$, and 331 are financially stable (42.9\%). Panel data were given in a cross-table view, and the model was based on that data. Table 3 shows the descriptive statistics of the financial statements setting out the financial conditions of enterprises in the whole sampling.

Table 3.

\section{Descriptive statistics of internal financial indicators}

\begin{tabular}{l|l|l}
\multicolumn{1}{c|}{ Variables } & \multicolumn{1}{c|}{ Mean } & \multicolumn{1}{c}{\begin{tabular}{c}
\multicolumn{1}{c}{ Standard } \\
deviation
\end{tabular}} \\
\hline Equity ratio & 41.42 & 32.96 \\
\hline Return on assets & -0.31 & 213.58 \\
\hline Total return & -7.58 & 553.65 \\
\hline Net assets & 103524.83 & 330749.97 \\
\hline Earnings before taxes & 22978.45 & 137118.09 \\
\hline Fixed assets & 81078.99 & 238980.45 \\
\hline Capital \& reserves & 103507.95 & 330733.91 \\
\hline Return on equity & 84859.89 & 265432.55 \\
\hline
\end{tabular}

Table 4 presents external factors characterizing the macroeconomic situation, namely the key interest rate, consumer price index, as well as the polynomial coefficients of the 4th degree listed on the stock exchange.

All the financial indicators are annual. However, exchange rates and the price of Brent change daily, hence to bring the daily values to the annual quantities in the calculations it is proposed to apply an approximation in the form of polynomials of degree $n$. To do this, it is necessary:

1. To determine a polynomial function for each year and for each variable.

2. To incorporate the coefficients in the polynomial function as separate modeling variables: 
Table 4.

Descriptive statistics of macroeconomic factors

\begin{tabular}{|c|c|c|c|}
\hline Variable & Mean & Standard deviation & Designations \\
\hline Key interest rate & 0.075 & 0.004 & rate \\
\hline Consumer price index & 1.082 & 0.023 & сpi \\
\hline Dollar currency polynomial constant & 31.817 & 1.194 & cusd \\
\hline Dollar currency polynomial trend & -0.009 & 0.124 & tusd \\
\hline Dollar currency polynomial square trend & 0 & 0 & t2usd \\
\hline Brent crude oil polynomial constant & 106.35 & 0.80 & cbrent \\
\hline Brent crude oil polynomial trend & 0.40 & 0.30 & tbrent \\
\hline Brent crude oil polynomial square trend & 0.00 & 0.01 & t2brent \\
\hline Euro currency polynomial constant & 41.22 & 1.29 & ceuro \\
\hline Euro currency polynomial trend & 0.15 & 0.22 & teuro \\
\hline Euro currency polynomial square trend & -0.01 & 0.01 & t2euro \\
\hline
\end{tabular}

$$
\begin{aligned}
& f_{i}\left(x_{t}\right)=\alpha_{0}^{i}+\alpha_{1}^{i} t+\alpha_{2}^{i} t^{2}+\ldots+\alpha_{j}^{i} t^{j}+\ldots+\alpha_{n}^{i} t^{n}+\varepsilon^{i} \\
& f_{i}\left(z_{t}\right)=\alpha_{0}^{i}+\alpha_{1}^{i} t+\alpha_{2}^{i} t^{2}+\ldots+\alpha_{j}^{i} t^{j}+\ldots+\alpha_{n}^{i} t^{n}+\varepsilon^{i} \\
& f_{i}\left(o_{t}\right)=\alpha_{0}^{i}+\alpha_{1}^{i} t+\alpha_{2}^{i} t^{2}+\ldots+\alpha_{j}^{i} t^{j}+\ldots+\alpha_{n}^{i} t^{n}+\varepsilon^{i}
\end{aligned}
$$

where $t$ - the time factor, $t=\overline{1, T}$;

$x_{t}-$ the dollar-ruble exchange rate at time $t$;

$z_{t}$ - Euro exchange rate against the ruble at time $t$;

$o_{t}$ - the cost of Brent crude oil (dollars per barrel) at time $t$; $f_{i}\left(x_{t}\right), f_{i}\left(z_{t}\right), f_{i}\left(o_{t}\right)$ - changes in macroeconomic models based on polynomial approximation to the $i$-th year;

$i$ - year of assessment of changes in macroeconomic factors, $i=\overline{1, I}$;

$\alpha_{0}^{i}$ - free term of a polynomial function in the $i$-th year;

$\alpha_{j}^{i}$ - coefficients of the $j$-th polynomial in the $i$-th year, $j=\overline{1, n}$;

$n$ - degree of the polynomial;

$\varepsilon^{i}$ - residuals error in the $i$-th year.

The polynomial coefficients of the variables are presented in Table 5.

To provide the key interest rate in an annual value, we propose to use weighted average values. The days during which the rate operates serve as a weight:

$$
r_{j}^{i}=\sum_{k=1}^{K} \frac{r_{k}^{i} \cdot n_{k}^{i}}{365}
$$

where $r_{j}^{i}$ - the weighted average of the key interest rate or tax rate of the $j$-th species in the $i$-th year;

$j-$ key interest rate or tax rate; $r_{k}^{i}-$ current key interest rate or tax rate varying $k$ times in the $i$-th year;

$n_{k}^{i}$ - number of days in the $k$-th period, during which key interest rate or tax rate remained constant in the $i$-th year;

$k$ - number of periods during which the key interest rate or tax rate were changing in the $i$-th year, $k=\overline{1, K}$.

Table 5.

Polynomial coefficients

of macroeconomic factors

\begin{tabular}{l|l|l|l}
\hline \multicolumn{1}{c|}{ Variable } & \multicolumn{1}{c|}{ Gonstant } & \multicolumn{1}{c}{ t } & \multicolumn{1}{c}{ t2 } \\
\hline usdrub_2012 & 32.44 & -0.18000 & 0.00325 \\
\hline usdrub_2013 & 30.24 & 0.00000 & 0.00000 \\
\hline usdrub_2014 & 32.92 & 0.13000 & -0.00180 \\
\hline brent_2012 & 105.43 & 0.70200 & -0.00979 \\
\hline brent_2013 & 107.35 & 0.54000 & -0.01000 \\
\hline brent_2014 & 106.098 & 0.00000 & 0.00630 \\
\hline eurorub_2012 & 40.8964 & -0.09983 & 0.00159 \\
\hline eurorub_2013 & 39.87 & 0.08700 & -0.00425 \\
\hline eurorub_2014 & 42.9 & 0.44000 & -0.01200 \\
\hline
\end{tabular}

The weighted average key interest rate for the period from 2012 to 2014 for each day is shown in the Table 6. The consumer price index from 2012 to 2014 is presented in Table 7. 
Table 6.

Weighted average values of key interest rate

\begin{tabular}{c|c}
\hline Year & Value \\
\hline 2012 & 0.0807 \\
\hline 2013 & 0.0744 \\
\hline 2014 & 0.0719 \\
\hline
\end{tabular}

\section{The proposed model}

To solve the problem of predicting the probability of financial instability in times of crisis with large fluctuations in financial and currency markets, in an unstable economy, it is necessary to take into account changes in the macroeconomic situation, such as changes in the currency exchange rates, the price of Brent oil crude, the size of the key interest rate and tax rates.

The decision tree method has been chosen to assess the financial stability of enterprise, since this method is relatively simply constructed and interpreted. There are many variants of the decision tree method. However, the CRT method (classification and regression tree) was best suited for the given sample. Since the dependent variable is a binary, as a result of its partition two subclasses are revealed. These subclasses classify the dependent variable in the best way.

As a result of construction of decision tree with 5 levels, 9 terminal nodes were identified. Splitting/partition into subclasses took place in the variables "Inventories", "Net assets" and "Fixed assets".

Table 8 presents the number of observations stuck in each terminal node, as well as the cumulative percentage.

Table 8

\section{Terminal nodes}

frequency table

\begin{tabular}{c|c|c|c}
\hline $\begin{array}{c}\text { Terminal } \\
\text { node }\end{array}$ & Frequency & Percentage & $\begin{array}{c}\text { Gumulative } \\
\text { percentage }\end{array}$ \\
\hline 1 & 265 & 34.4 & 34.4 \\
\hline 3 & 113 & 14.7 & 49.0 \\
\hline 8 & 86 & 11.2 & 60.2 \\
\hline 11 & 54 & 7.0 & 67.2 \\
\hline 12 & 40 & 5.2 & 72.4 \\
\hline 13 & 99 & 12.8 & 85.2 \\
\hline 14 & 44 & 5.7 & 90.9 \\
\hline 15 & 35 & 4.5 & 95.5 \\
\hline 16 & 35 & 4.5 & 100.0 \\
\hline Total & $\mathbf{7 7 1}$ & $\mathbf{1 0 0 . 0}$ & \\
\hline
\end{tabular}

Table 7.

Weighted average values of consumer price index

\begin{tabular}{c|c}
\hline Year & Value \\
\hline 2012 & $106.59 \%$ \\
\hline 2013 & $106.48 \%$ \\
\hline 2014 & $111.33 \%$ \\
\hline
\end{tabular}

Almost $50 \%$ of all observations were in the first and third terminal units/nodes, and $34.4 \%$ of these fell in the first node.

The probability that the company will be financially unstable is $88.3 \%$ on condition that its net assets will be less than 4006 thousand Rubles (terminal node 1). However, most likely, $94.2 \%$ - the onset of financial instability is typical for companies whose net assets are less than 53524 thousand Rubles, and inventories more than 19240 Rubles (terminal node 8). If inventories are less than a predetermined level of 19240 thousand Rubles, then, provided that the net assets are less than 18797 thousand Rubles, the likelihood of financial instability is estimated at $77.5 \%$ (terminal node 11). Otherwise, the company can be characterized as financially stable with a probability of $88 \%$ (terminal node 12 ).

Companies having inventories of more than 165973 thousand Rubles, and net assets ranging from 56524 thousand Rubles up to 456493 thousand Rubles are predicted as financially unstable with a probability of $94.3 \%$ (terminal node 15).

The companies having inventories less than 165973 thousand Rubles and fixed assets not exceeding 87731 thousand Rubles are deemed to be financially stable with a probability of $100 \%$ (terminal node 13 ). If the fixed assets are more than 87731 thousand Rubles, we can claim them as financially stable with a probability of $60 \%$.

Thus, as a result of the analysis, we can conclude that in order to achieve financial stability enterprises should optimize their operating activities. It is obvious that if inventories are large and net assets are relatively small, the onset of financial instability is inevitable.

The accuracy of the modelling on the training set was $86.4 \%$, and testing set $-85.5 \%$.

The first category of errors (the financially unstable company is recognized as financially stable) on training set constitutes is 38 observations. Errors of the second category (financially unstable companies are classified as financially stable) is 37 observations. The number of the first and the second error types constitutes 16 observations on a testing set (Table 9). 


\section{Accuracy of the model}

\begin{tabular}{|c|c|c|c|c|}
\hline & \multirow{2}{*}{ Sample } & \multicolumn{2}{|c|}{ Predicted } & \multirow{2}{*}{$\begin{array}{l}\text { Percent } \\
\text { Correct }\end{array}$} \\
\hline & & 0 & 1 & \\
\hline \multirow[t]{3}{*}{ Training } & 0 & 285 & 38 & $88.2 \%$ \\
\hline & 1 & 37 & 191 & $83.8 \%$ \\
\hline & Overall percentage & $58.4 \%$ & $41.6 \%$ & $86.4 \%$ \\
\hline \multirow[t]{3}{*}{ Test } & 0 & 102 & 16 & $86.4 \%$ \\
\hline & 1 & 16 & 86 & $84.3 \%$ \\
\hline & Overall percentage & $53.6 \%$ & $46.4 \%$ & $85.5 \%$ \\
\hline
\end{tabular}

Only internal financial indicators were used in the construction of the tree solution model. Those are net assets, fixed assets and inventories. To identify the impact of macroeconomic factors, it is necessary to run a non-parametric test to determine the equality of averages for the intervals according to which the tree split.

Table 10 shows the test results on determining the equality of averages of macroeconomic factors according to the subclasses derived from the decision tree method.

Table 10 shows that the hypothesis on the averages of the variable "Brent constant" divided by the variable "Net assets" to groups are different is accepted at the $10 \%$ level. Therefore, one can argue that Brent crude oil prices have an impact on the financial stability of enterprises in the metallurgical industry. Given the high cor- relation between the price of Brent crude oil and the rates of national currency against the dollar and the euro, we can argue that there is an effect of the afore-mentioned factors on the financial stability of the enterprise.

\section{Conclusion}

Thus, the proposed approach allows us to take into account macroeconomic factors with changing frequencies different from the frequencies of changes in the financial performance of the enterprise. The approach is based on the presentation of the time series as a polynomial function to some extent. For each of three years and for each of three variables a polynomial function was built. To calculate the probability of financial instability as characteristics of selected factors in the final model, the coefficients of polynomial functions of 2 nd degree are used. The proposed approach of macroeconomic factors aggregation decomposes each factor into three variables with no significant loss of information

A model of tree solution with the CRT method and with a 5-level depth was built. As a result of splitting the variables into "Net assets", "Inventories" and "Fixed assets", a model with 9 terminal nodes was obtained. The accuracy of the model on the training set was $86.4 \%$. On the test set $-85.5 \%$.

The average value of the variable constant "Brent oil crude" of the polynomial function for financially stable and financially unstable companies on the basis of the nonparametric test on the equality of the average values has significant differences. This confirms the assump-

Nonparametric test comparing means for independent samples within each variable

\begin{tabular}{|c|c|c|c|}
\hline \multirow{2}{*}{ Null hypothesis } & \multicolumn{3}{|c|}{ p-value } \\
\hline & Fixed assets & Inventories & Net assets \\
\hline the distribution of rate is the same & 0.725 & 0.594 & 0.314 \\
\hline the distribution of $\mathbf{p p i}$ is the same & 0.98 & 0.84 & 0.648 \\
\hline the distribution of cusd is the same & 0.98 & 0.84 & 0.648 \\
\hline the distribution of tusd is the same & 0.725 & 0.594 & 0.314 \\
\hline the distribution of t2usd is the same & 0.725 & 0.594 & 0.314 \\
\hline the distribution of ceuro is the same & 0.71 & 0.39 & 0.09 \\
\hline the distribution of teuro is the same & 0.725 & 0.594 & 0.314 \\
\hline the distribution of $\mathbf{t 2 e u r o}$ is the same & 0.98 & 0.84 & 0.648 \\
\hline the distribution of cbrent is the same & 0.98 & 0.84 & 0.648 \\
\hline the distribution of tbrent is the same & 0.725 & 0.594 & 0.314 \\
\hline the distribution of $\mathbf{t} \mathbf{2} \mathbf{b r e n t}$ is the same & 0.725 & 0.594 & 0.314 \\
\hline
\end{tabular}


tion about the impact of oil on the financial condition of an enterprise.

The "Net assets" value should correspond to the value of the "Inventories". If the "Inventories" exceed a cer- tain level, there is a great probability of financial instability. Otherwise, the company is rated as financially stable. Thus, results of the model allow us to give some recommendation for CEOs concerning financial stability.

\title{
References
}

1. Beaver W.H. (1966) Financial ratios as predictors of failure. Empirical research in accounting selected studies. Supplement to Journal of Accounting Research, no. 40, pp. 71-111.

2. Altman E.I. (1968) Financial ratios. Discriminant analysis and the prediction of corporate bankruptcy. The Journal of Finance, no. 20, pp. 589-609.

3. Deakin E.I. (1972) A discriminant analysis of predictors of business failure. Journal of Accounting Research, no. 12, pp. 167-179.

4. Edmister R.O. (1972) An empirical test of financial ratio analysis for small business failure prediction. The Journal of Financial and Quantitative Analysis, no. 16, pp. 1477-1493.

5. Blum M. (1974) Failing company discriminant analysis. Journal of Accounting Research, vol. 24, no. 1, pp. 1-25.

6. Chesser D. (1974) Predicting loan noncompliance. Journal of Commercial Bank Lending, no. 13, pp. 2-15.

7. Ohlson J. (1980) Financial ratios and the probabilistic prediction of bankruptcy. Journal of Accounting Research, no. 22, pp. 109-131.

8. Bogdanova T.K., Alekseeva Yu.A. (2011) Prognozirovanie veroyantosti bankrotstva s uchetom izmeneniya finansovyh pokazateley $\mathrm{v}$ dinamike [Forecasting the probability of bankruptcy to reflect changes in financial indicators in dynamics]. Business Informatics, no. 1 (15), pp. 50-60 (in Russian).

9. Gorbankov S.A., Beloliptsev I.I. (2013) Gibridniy metod otsenki riska bankrotstva na base bayesovskogo ansamblya neyrosetei i logit-transformatsii [Hybrid method for estimating the risk of bankruptcy based on the Bayesian ensemble of neural networks and logit models]. Naukovedenie, no. 6, pp. 1-11 (in Russian).

10. Nedosekin A.O. (2003) Metodologicheskie osnovy modelirovaniya finansovoi deyatel'nosti s ispol'zovaniem nechetko-mnozhestvennyh opisaniy [Methodological basis for modeling of financial activity using fuzzy sets descriptions]. Doctoral dissertation. Saint Petersburg (in Russian).

11. Bogdanova T.K., Shevgunov T.Ya., Uvarova O.M. (2013) Primenenie neyronnykh setey dlya prognozirovaniya platezhesposobnosti predpriyatiy obrabativayushey otrasli [Application of neural networks for solvency prediction for Russian companies of manufacturing industries]. Business Informatics, no. 2 (24), pp. 40-48 (in Russian).

\section{Моделирование финансовой устойчивости предприятия с учетом макроэкономических показателей}

\section{Д.С. Биджоян}

аспирант кафедры бизнес-аналитики, аспирантская школа по экономическим наукам

Национальный исследовательский университет «Высшая школа экономики»

Адрес: 101000, г. Москва, ул. Мясницкая, д. 20

E-mail: bidzhoyan_david@mail.ru

\section{T.K. Богданова}

кандидат экономических наук, доцент кафедры бизнес-аналитики

Национальный исследовательский университет «Высшая школа экономики»

Адрес: 101000, г. Москва, ул. Мясницкая, д. 20

E-mail:tanbog@hse.ru

\begin{abstract}
Аннотация
В настоящее время предприятия функционируют в условиях быстроизменяющейся макроэкономической ситуации. Вследствие этого появляется необходимость учета макроэкономических факторов при прогнозировании как финансового состояния предприятия в целом, так и различных его аспектов. Однако при включении макроэкономических факторов в модель, прогнозирующую финансовое состояние предприятия, возникает проблема, связанная с тем, как включать факторы, которые имеют частоту измерения, отличную от частоты измерения внутренних финансовых показателей. Так, динамика изменения курсов валют и цен на нефть
\end{abstract}


может быть разной, например, ежеминутной, ежедневной, еженедельной и т.д. Изменение ключевой ставки не носит систематический характер, оно связано с реакцией Центрального Банка на изменение конъюнктуры рынка. Финансовые показатели предприятия публикуются в полугодовых и годовых отчетах.

В статье предложен подход к агрегированию макроэкономических факторов, заключающийся в представлении временного ряда каждой переменной для каждого года с последующим включением полиномиальных коэффициентов в конечную модель в качестве характеристик исходной переменной. Для ключевой ставки рассчитывается средневзвешенный показатель, где в качестве весов выступают дни, в течение которых действовала ставка. На основе данных 291 предприятия металлургической отрасли Приволжского федерального округа за период с 2012 по 2014 годы построена модель оценки финансовой устойчивости на основе метода дерева решений методом CRT (Classification and regression tree). Точность модели составляет приблизительно 86\%. Структура полученного дерева решений позволила дать рекомендации по оптимизации определенных финансовых показателей, характеризующих операционную деятельность предприятия, для достижения им финансовой устойчивости.

Ключевые слова: финансовая устойчивость, агрегирование макроэкономических факторов, полиномиальная функция, дерево решений, запасы, чистые активы, основные средства, ключевая ставка, индекс потребительских цен.

Цитирование: Bidzhoyan D.S., Bogdanova T.K. Modelling the financial stability of an enterprise taking into account macroeconomicindicators // Business Informatics. 2016. No. 3 (37). P. 30-37. DOI: 10.17323/1998-0663.2016.3.30.37.

\section{Литература}

1. Beaver W.H. Financial ratios as predictors of failure. Empirical research in accounting selected studies // Supplement to Journal of Accounting Research. 1966. No. 40. P. 71-111.

2. Altman E.I. Financial ratios. Discriminant analysis and the prediction of corporate bankruptcy // The Journal of Finance. 1968. No. 20. P. 589-609.

3. Deakin E.I. A discriminant analysis of predictors of business failure // Journal of Accounting research. 1972. No. 12. P. 167-179.

4. Edmister R.O. An empirical test of financial ratio analysis for small business failure prediction // The Journal of Financial and Quantitative Analysis. 1972. No. 16. P. 1477-1493.

5. Blum M. Failing company discriminant analysis // Journal of Accounting Research. 1974. Vol. 24, No. 1. P. 1-25.

6. Chesser D. Predicting loan noncompliance // Journal of Commercial Bank Lending. 1974. No. 13. P. 2-15.

7. Ohlson J. Financial ratios and the probabilistic prediction of bankruptcy // Journal of Accounting Research. 1980. No. 22. P. $109-131$.

8. Богданова Т.К., Алексеева Ю.А. Прогнозирование вероятности банкротства с учетом изменений финансовых показателей в динамике // Бизнес-информатика. 2011. № 1 (15). С. 50-60.

9. Горбатков С.А., Белолипцев И.И. Гибридный метод оценки риска банкротства на базе байесовского ансамбля нейронных сетей и logit-модели // Науковедение. 2013. № 6. С. 1-11.

10. Недосекин А.О. Методологические основы моделирования финансовой деятельности с использованием нечетко-множественных описаний / Дис. ... д-ра экон. наук. СПб, 2003. 280 с.

11. Богданова Т.К., Шевгунов Т.Я., Уварова О.М. Применение нейронных сетей для прогнозирования платежеспособности российский компаний обрабатывающей отрасли // Бизнес-информатика. 2013. № 2 (24). С. 40-48. 